\title{
Public Accountability through Merit Values on Civil Service Management in Central Java Province
}

\author{
Septiana Dwiputrianti \\ Public Development Administration Postgraduate Program, School of Public Administration, National Institute \\ of Public Administration (STIA LAN); Assistant Commissioner - Indonesian Civil Service Commission. \\ (email: tiana.dwi@kasn.go.id)
}

\begin{abstract}
Data indicates that implementation of the merit system in civil service management is still far from the target achievement, especially for local governments. This paper assesses the implementation of the merit system of ASN management based on 8 (eight) aspects at the Central Java Province, namely: planning; procurement; career development and development of competencies; promotion, mutation, rotation and demotion; performance management; payroll, reward, and discipline; protection; and supporting facilities. The research instrument was developed from national policies. This study found that Central Java has met category III (good implementation) for 5 aspects. However, it reveals there are still 3 (three) aspects that haven't met the criteria for good implementation. There are some impediments for implementation in career development, promotion and rotation, and performance management aspects. This finding is very important as a basic reference in the policy evaluation and supporting the bureaucratic reform performance. The recommendation focuses on the development of talent management and talent pool as one of the Indonesian strategic plans to improve the quality of civil service.
\end{abstract}

\section{Keywords:}

merit; civil service governance; Central Java; civil service; governance; merit

\section{Introduction}

To anticipate rapid global change, the government must build a more dynamic governance system. The Government of Indonesia (GOI) is putting effort into adopting policies to accelerate economic growth and to face uncertain global environmental changes. In achieving the objectives of the state to increase economic growth and welfare, to improve the quality of public services, and to provide more effective policy formulation and evaluation, Indonesia is giving more attention to the development of its human resources apparatus. This is especially aimed at providing bureaucratic leaders who can think ahead, and learn from other countries or organizations. The GOI has anticipated this problem by issuing Law Number 5 of the year 2014 on the Civil Service (UU-ASN) to realize a 
professional, neutral, and high integrity Civil Service (ASN) through the implementation of a merit system in ASN policy and management. Implementation of the UU-ASN has provided a solid foundation for transforming the management of the state civil apparatus from an administrative and rule-based approach, towards a performance-based approach with human capital development implementation. This transformation is expected to improve the quality of public policy to encourage the development of the business world and the acceleration of economic growth. Enactment of the UU-ASN is expected to encourage the realization of excellent service to the society and the business world, increasing Indonesia's competitiveness globally, contributing to sustainable economic growth, and avoiding Indonesia from the threat of the middle-income trap phenomenon.

Various international studies show that there is a positive correlation between the level of governance quality and the progress of a country, especially in the achievement of economic development and the quality of life of the people. The quality of governance can be seen from various indicators or parameters, such as the Global Competitiveness Index, Ease of Doing Business (EODB), Government Effectiveness Index, and Corruption Perceptions Index (CPI). The progress of governance quality in the Indonesian government and its comparison with other ASEAN countries is shown in Table 1.

Table 1 shows in terms of the quality of governance, Indonesia is still lagging behind other countries in ASEAN, especially Malaysia and Thailand. As is known, the quality of governance is strongly influenced by the management system and performance of the State Civil Apparatus (ASN). Government efforts to realize an efficient, effective, and highperformance bureaucracy have shown results. This is evident from the World Economic Forum (WEF) report that Indonesia's competitiveness rating rose 5 (five) levels in 2018. Nevertheless, the report still highlights some of the problems faced related to the ease of doing business in Indonesia: (i) corruption; (ii) bureaucratic inefficiency; (iii) availability of infrastructure. Based on these key issues, the Government of Indonesia is advised to prioritize corruption prevention efforts in various fields, particularly those related to business and investment development, and focus on implementing bureaucratic reforms to improve government bureaucracy inefficiencies and improve infrastructure development.

In addition to the Competitiveness Index, one of the parameters used by the business community in making investment decisions is the Ease of Doing Business (EODB) index. 
Based on the EODB survey of 2018 published by the World Bank, the ease of doing business in Indonesia rose from 91 to 72, up 19 levels. This rating increase is a positive result achieved from various policy improvements and institutional arrangements by the bureaucracy including the civil state apparatus.

One indicator that reflects the performance of government bureaucracy is the government effectiveness index (Government Effectiveness). Assessment of government effectiveness is formulated from several parameters such as public perception on public service quality, public service quality and government independence from political pressure, quality of policy formulation and implementation, and government commitment in implementing policy. The effectiveness score of the Indonesian Government in 2018 rose from 46 to 53 , so that the ranking rose from 121 to 98 . To be able to catch up with other ASEAN countries, the Indonesian Government must continuously improve the quality of governance and build a professional civil state apparatus, integrity, and high performance through an acceleration of bureaucratic reform implementation.

Everest-Phillips (2015: 94-98) argues that meritocracy can promote social mobility and can benefit individuals and society at large. He explores the case of Singapore that turned meritocracy into a development factor. It found that development is closely linked with building a civil service meritocracy state and fostering public administration through motivation, promotion, the rule of law, integration, and non-tolerance of corruption. The author explains what benefits are caused by meritocracy and the impacts on humans and society. These arguments provide insight for those implementing merit systems as a means to provide the best service and reach their maximum potential. The author also gives examples of outcomes in countries that implement this meritocracy system, such as its role in promoting higher economic growth, improving civil service performance and the performance of civil servants, accountability assessed by citizens, and a reduction in corruption. He also said that if Singapore wants to succeed then it must have a system that allows the best and most appropriate people to be in the jobs that need them. Since this merit principle has been applied, since 1965, Singapore has significantly increased per capita income. Lee Kuan Yew puts more emphasis on the success of his understanding of the need for good public administration in creating a clean, efficient, effective, and best of all public service ethos. Lee Kuan Yew instilled in public officials a sense of urgency and purpose, efficiency and 
impartiality, law and excellence in decision making, and zero tolerance for corruption. It is also important that meritocracy does not eliminate the need for transparency, accountability, and rule of law.

Besides, Svensson and Wood (2009) examine the measurement of public sector organizations in Sweden to communicate and implement a code of ethics to public services. They employed a longitudinal survey approach. It concludes that public sector organizations in Sweden have few formal rules and regulations in place. The regulations related to the code of ethics and code of conduct for employees encourage leaders and staff to behave correctly than pinpointing what to do or what not to do. Moreover, Tong, Jeffrey, and Walter (1999) emphasized an important element in reforming by applying a merit system in human resource management. This includes evaluating performance by rewarding employees and imposing sanctions on non-performing employees. Open and fair competition in the selection and promotion process to assure the quality of government employees. Besides, the rules underpin the existence of sustainability and consistency in government policy. Building administrative and staffing professionalism is the biggest challenge. Problems such as abuse of authority, inefficiency, favoritism, excessive staffing, closeness, and corruption become intolerable. China has built a high quality of human resources and successfully pushed the country toward modernization and has a performance system that is quite effective. The principle of openness, justice, competition, and selection to get the best employees is the process undertaken so far by China in carrying out administrative reform of bureaucracy in government.

Furthermore, Yoon and Kim (2016), emphasize the importance of different skill components based on the type of work employees. They are differentiating the skills of an employee both at the central and regional levels based on the aspects of prevention, preparedness, responding, and improving things. Thus, these aspects become the focus of human resource management in the public sector, including in the process of selection or procurement of employees, education, training, and performance management. While Ko and Walter (2013), states that Human Resource Management in practice has a significant contribution to organizational commitment, organizational behavior, and encourage the performance of the organization. The facts show that a working system based on high performance, is identified with the recruitment process is very selective, development and 
effective training, performance evaluation continuous, the reward for fair performance, and decentralized decision-making is good with a promotion based on a merit system.

Harel and Tzafir (2001) show out that the public sector has begun to move closer to a private sector model that adopts high performance-based work practices. This is as a result of the increasing demands and needs of the people on the performance of good bureaucratic services. Based on this, the selection process of employees and leaders in government becomes an absolute thing done to get professional human resources and can show high performance. Cho, et. al. (2013), remained the concept of bureaucracy Weber, where the application of the merit system in the selection process is done to encourage professionalism in the bureaucracy, high-performance, and compliance with applicable regulations in comparison with the trend of political connections.

In Indonesia, the merit system is the policy for management of all ASN based on qualifications, competencies, and performance without distinction of political background, race, color, religion, origin, sex, marital status, age and disability conditions (Law Number 5/2014 about Civil Service, ASN Law). Since the enactment of the UUASN in 2014, the implementation of a merit system in ASN management has become an obligation for all governments at the central and regional levels and is evaluated by the State Civil Service Commission (KASN). Pardede and Mustam (2017), examine the management of ASN in Semarang regency. Based on the results of their study, they emphasize the importance of human resources in public sector organizations. Chassamboulli and Gomes (2017) underline how important recruitment policy and incentives are in public sector organizations. However, they found that some state recruitment and government payments did not follow meritocracy practices. The meaning of the merit system in Government Regulation Number 11 the Year 2017 about the management of civil servants, subsection 134, paragraph 2, covers the criteria of implementation of selection and promotion is to be open; and implementation of the code of ethics and code of conduct of ASN Employees.

The purpose of applying the merit system in open selection is to be able to recruit professional high integrity ASNs and place them in government bureaucratic posts according to their competence; maintain ASN through fair and reasonable compensation; develop ASN capability through guidance and training; and protect ASN careers from politicization and policies that go against the merit principle (nepotism, primordialism, etc.). KASN serves to 
oversee the implementation of basic norms, code of conduct, and code of ethics and also to implement the Merit System in ASN policies and Management of Government Agencies (subsection 30 ASN Law).

Why should open selection become more popular than the application of merit systems in other aspects of ASN management? This is because the open selection is a quick win for merit system implementation and aims to get the right people according to the needs of the organization. Another thing that is not less important is that open selection can also overcome the spoil system and the sale and purchase of positions and increase the mobility of ASN.

The merit system is the opposite of the spoil system, which is a system in which positions in government are filled by friends, family, or supporters of the ruling party. The merit system was well known in the Qin and Han dynasties in China. The system was developed so that government positions were not only occupied by nobles but also capable of rural residents. The system was later adopted by the British Indian government in the 17th Century and subsequently developed in Europe. In the United States, the merit system began to be implemented in the 18th Century. The aim is to provide the public with competent, honest, and productive officials who can create quality public servants.

There are 9 (Nine) principles of merit that are used in staffing management in government circles in the United States, namely:

1. Recruit, select and prioritize based on open and fair competition;

2. Treat the Civil Service Officials fairly and equally;

3. Provide equal remuneration for equal work and reward high performance;

4. Maintain high standards for integrity, behavior, and concern for the benefit of the community;

5. Managing State Civil Servants effectively and efficiently;

6. Maintaining or separating Civil Servants based on the resulting performance;

7. Allowing developing competencies to the Civil Service Officials;

8. Protecting Civil Servants from improper political influences;

9. Protecting Civil Servants from unjust and not open laws.

Also, there are 4 (four) categories that are prohibited in the management of staffing, namely discrimination, recruitment practices that violate the merit system, efforts to retaliate 
against protected activities (including whistleblowers), and violations of various regulations based on the principles of the merit system. The four categories mentioned above, if explained, the employment practices that are prohibited in the merit system are as follows:

1. Conducting discrimination against State Civil Servants or prospective Civil Servants based on ethnicity, religion, race, religion, gender, regional origin, age, physical limitations, marital status or certain political affiliations;

2. Requesting or considering work recommendations based on factors other than knowledge or abilities related to work;

3. Forcing someone's political activities;

4. Deliberately or deceived activities by blocking anyone from competing for work;

5. Influencing people to withdraw from the competition to increase or reduce one's employment prospects;

6. Giving an illegitimate preference or advantage to someone to increase or reduce the employment prospects of a prospective Civil Service Officer;

7. Practicing nepotism, including contracting, promoting, and supporting the appointment or promotion of one's relatives or relatives;

8. Retaliating against whistleblowers;

9. Taking or failing to take action against State Civil Servants or Prospective Civil Servants who submit appeals, complaints, or complaints with or without providing information that causes someone to violate regulations;

10. To discriminate based on the behavior of someone who is not related to work and does not affect the performance of the State Civil Servants or Prospective Civil Apparatus;

11. Taking or failing to take action on the State Civil Servants who if taking or failing to take such actions will violate laws or other rules that are directly related to violating the principles of the merit system;

12. Carry out or impose closed / fewer open policies or decisions related to whistleblower rights.

In Australia, the application of a merit system is considered important in ensuring recruitment is carried out fairly and competitively and free from political influence and other 
non-merit factors. Therefore, recruitment in the public sector in Australia is regulated as follows:

1. The vacant position must be announced;

2. Skills and job requirements must be determined;

3. Assessment criteria must be determined and announced to candidates;

4. Decisions must be based on a comparison between criteria and assessment results;

5. The process must be open for applicants to be given accuracy to apply;

6. The people recommended are the best;

7. Decisions can be tested and there is no conflict of interest.

With all those principles in mind, the Government of Indonesia has established a policy to implement a deep merit system.

\section{Methods}

This research uses a descriptive qualitative research method. Sources of data for this study are primary data obtained from collecting data from instruments and informants. Data analysis is evidence-based data, data presentation from respondents, verification, and conclusion. Primary data were obtained from government institutions both Ministries and Local Government agencies, and secondary data from government laws and documents and other resources. The main results of the study are external and internal supports and other great challenges to applying the merit system in Indonesian government institutions.

In reviewing how far the implementation of ASN management practices in government agencies has been based on the principle of merit, KASN has conducted a mapping of the Implementation of Merit Systems in Government Agencies through rapid assessment. This is based on the criteria as set out in the Indonesian Civil Service Commission (KASN) Regulation Number 9 of the Year 2019 concerning Procedures for Self-Assessment in Implementation of Merit Systems in ASN Management for Government Agencies. There are 9 (nine) criteria are as follows:

1. Have a 5-year ASN requirement plan detailed by type and level of position and arranged based on position analysis and job analysis taking into account employees entering retirement; 
2. Conducting open and competitive recruitment of employees, both from the civil service candidates and also from civil servants from other agencies;

3. Have career development policies and programs that begin with talent mapping, competency gap analysis and performance gaps, strategies and programs to address gaps and form a talent pool and succession plan;

4. Implementation of performance management, which starts with setting performance targets, periodically evaluating performance by using objective methods;

5. Analyzing performance gaps and having strategies to solve the performance problems both in organization and individual of civil services;

6. Link payroll, awarding, and promotion policies to performance and discipline;

7. Carry out promotions, mutations objectively and transparently based on suitability of qualifications, competencies, and performance by utilizing the Talent Pool;

8. Protect so that employees can carry out their duties properly and provide services to ASN;

9. Has a support system such as an integrated staffing information system, assessment center, and other applications that support the implementation of ASN management.

\section{Results and Discussion}

A merit system is an ASN policy and management that is based on fair and reasonable qualifications, competencies, and performance regardless of political background, race, color, religion, origin, gender, marital status, age, or disability condition. This system realizes a recruitment and promotion system based on merit or the capabilities of ASN employees. The system was officially adopted in the Indonesian Government's bureaucracy in the last four years ago, with the enactment of Law no. 5 of 2014 concerning State Civil Apparatus (ASN Law). The system was introduced to improve the ASN's professionalism, neutrality, integrity, and performance. The ultimate goal is to create a government bureaucracy that is efficient, effective, clean, responsible, and serving.

To ensure the merit system is implemented following the provisions, the ASN Law also mandates the establishment of KASN, a nonstructural institution that is independent and free from political interventions that are given the authority to monitor and evaluate the implementation of ASN policies and management to ensure the realization of a merit system. 
To carry out this task, KASN has conducted supervision over the implementation of open selection in filling the High Leadership Position (JPT). Supervision is carried out: (1) preventively through the dissemination of procedures for selection and issuance of recommendations on the implementation and results of the selection; and (2) repressively by following up on public complaints regarding alleged violations in the implementation of JPT filling and issuing recommendations based on the results of the investigation.

Besides, to ensure that agencies establish a comprehensive merit system, KASN evaluates with the aim of (1) knowing the extent to which the principles of merit have been applied in ASN management practices in government agencies; and (2) recommending improvements that still need to be done by agencies so that the principles of merit are accommodated in the management of ASN in government agencies. For this purpose, KASN has developed a merit system assessment instrument.

Figure 1 until Figure 4 shows the results of mapping merit principle implementation of civil service management in all levels of Indonesian Government agencies. The red one as category I (one) indicates 'Poor' implementation of a merit system with a score of around 100 until 174. The yellow one as category II (two) indicates 'Not too Bad' implementation of merit system with a score from 175 until 249. The green color one as category III (three) indicates 'Good' implementation of a merit system with a score from 250 until 324 . The best one is the blue one as category IV (four) indicates 'Very Good' implementation of a merit system with a score from 325 to 400 . The figures present that for ministries and non-ministries levels, most have reached category III (three) with Good implementation. This means that they have met most of the merit criteria. Meanwhile, those who have reached level IV only have 6 Ministries. As for most the local government level, either for Provincial Government, districts, and city levels, the majority are still at level II, meaning that they only meet some of the criteria set.

Moreover, for the development of the Merit System in Government Agencies. Besides mapping based on a rapid assessment, KASN also conducted an in-depth assessment for some ministries, non- ministries, and some Provincial Government, under KASN Regulation Number 9 of the Year 2019 concerning procedures for Self-Assessment in Implementation of the ASN management based on Merit System in Government Agencies. The aim is to know how far the principle of merit has been applied in the management of ASN in each Government Agency; Furthermore, in Providing input to agencies that are assessed 
concerning efforts that are still needed in efforts to apply the principle of merit. The evaluation and verification also focused on the process of preparing a talent pool, to ensure that employees who were included in the succession plan had met the requirements to be promoted. Thus, the agency can be excluded from the implementation of open selection, as mandated in Article 111 of ASN Law Number 5 of the year 2014. Evaluation is carried out using the self-assessment method, where each agency forms an appraisal team chaired by an Authorized Officer, who is given the task to carry out an assessment based on instruments that have been built by KASN. The results of the assessment along with supporting documents are then submitted to KASN for verification. Based on the results of verification, KASN will determine the level of application of the merit system to the agency assessed; and recommendations for improvement.

The assessment and verification show that from several government agencies that were assessed, and providing the evidence to be verified, only the Ministry of Public Works and Public Housing (Kementrian PUPR), the Ministry of Finance (Kementrian Keuangan - MOF), Ministry of Maritime Affairs and Fisheries (Kementrian Kelautan dan Perikanan), the Ministry of State-Owned Enterprises (Kementrian BUMN), the Coordinating Ministry for Economy, the Ministry of Agriculture, and the National Institute of Public Administration (Lembaga Administrasi Negara) have met almost all merit criteria and already have a talent pool with a succession plan that is supported by complete data. While for local government level, the Yogyakarta Provincial Government, Central Java Provincial Government, East Java Provincial Government, and West Java Provincial Government, the talent pool and succession plan that has been prepared and still needs to be sharpened and equipped with more accurate data. While others are still in the process of mapping competencies that will be the basis for developing a talent pool.

Besides, Figure 5 shows an overview of the Merit Values on Civil Service Management in Central Java Province. Data provides information that Central Java Province has not been optimized the career development system based on merit values. For the civil service planning aspect, long terms planning should be in line with the needs of the organization and local potential sectors in the central java province. In terms of career development, for competency standards in managerial, technical, and socio-cultural competencies, the Central Government Province has not yet provided completed for all levels of positions. Moreover, talent mapping 
has not been created based on the evaluation of competency standards for every level of positions (only for high and middle position levels). In terms of the succession plan, most local governments are not familiar, and don't know how to find the successors for the organization, includes the Central Government Province. Data and documents of gap competencies, the gap of performance, and how to analyze and strategy to solve the gap are not provided. Although these data and information are very important for the career development of civil service for the need of individuals and organizations. In terms of development competencies, civil servants are still familiar with classical training rather than non- classical pieces of training (such as e-learning, coaching, mentoring, project assignments, consultation, self-development, internship, benchmarking, exchange employees, secondment, etc. ).

Performance management in the Central Government Province has been done very well. Reward and punishment based on performance data have been implemented based on application and information technology. Both financial and non-financial awards have been received for high-performance employees. However, performance dialog has not been implemented well.

There are some problems and challenges faced in building a merit system in government agencies. First of all, is human resource and capital planning in the middle and long terms. Government agencies have drawn up plans for employee needs, which are arranged based on the number, position, and qualifications of positions, based on a job analysis (Anjab) and workload analysis (ABK) because these documents are a requirement for obtaining civil service candidates' (CPNS) formations from the Ministry of PANRB. However, the plans drawn up do not always reflect actual needs because Anjab and ABK are usually implemented against a standard organizational structure, which is not structured to realize targets in the RPJM and the strategic plan of the organization. As such, many of the proposed positions do not contribute to the achievement of targets in the RPJM and the Strategic Plan.

Besides, the planned needs are usually focused only on the needs of implementing staff, while vacancies are often also available for higher-level positions, especially with the existence of a moratorium on CPNS acceptance in the past. Needs at the supervisor, administrator, and JPT level are also described in the planning of employee needs. Thus the agency can make a strategy to meet the needs through the transfer of civil servants from other agencies and the appointment of non-PNS, according to the provisions. 
Secondly is the problem in career development and planned competency improvement. The CPNS procurement is now competitive and transparent, and the graduation determination has been based on merit. But many agencies generally do not have structured employee coaching programs. Several agencies have mapped employee competencies, but the results are only used for promotional purposes. Not many agencies analyze the results of the competency test to find out the competency gaps that each employee has because the agency has not set job competency standards. Though this information is very useful in designing employee training and competency improvement programs, through coaching, mentoring, apprenticeship, or training.

The third problem and challenge are in measuring an objective performance appraisal. One obstacle to implementing a merit system in ASN management is the poor management of apparatus performance. This can be seen from the large number of agencies that have not made a performance contract/performance agreement. Some agencies have made performance contracts with employees, but the performance targets set are not measurable so it is difficult to assess. Other than that. Performance appraisal methods used are not objective and measurable, and performance appraisal is not carried out regularly.

In general, Indonesian government agencies do not analyze the results of performance appraisal so it is unknown why many employees fail to achieve targeted performance. The unavailability of this information means that almost all agencies do not have a strategy to overcome the problem of the gap between targeted performance and employee performance. Consequently, employee performance is still not a major consideration in employee career development, as mandated by the merit system.

The fourth problem and the main problem in implementing the merit system in ASN management is Talent Pool Development and Succession Plan. A talent pool is a group of individuals who are identified as having the top talent to fill strategic positions in an organization. While the succession plan is a systematic process to identify and develop key Leadership Positions to ensure leadership continuity within the organization. The talent pool and succession plan are built to ensure that the agency has employees with the required competencies, now and in the future. Building a talent pool is part of building a merit system in government agencies. Through open selection, agencies can choose the best candidates from those who apply. But it is difficult to ensure that participants in the open selection are 
people who have the talents that the organization needs. For this reason, the development of a talent pool is important. At present, there are only a small number of agencies that have built a talent pool and have a succession plan. The obstacle is not yet able to provide basic data that is a complete profile of each employee. Agencies have generally carried out competency tests or managerial competency mapping of high-ranking officials, administrators, and supervisors, but the results of the mapping are usually only used for promotion and mutation. Employee profiles generated from the competency test process are not further analyzed so that they have not been utilized for career guidance and employee competency improvement.

Also, not many agencies have set technical competency standards and have instruments to assess the technical capabilities of their employees. Moreover, accurate performance data is also difficult to obtain because there are still many agencies that have not implemented a performance appraisal system objectively and measurably. Many agencies, especially the Regional Government, are still experiencing difficulties in setting performance targets because the organizational performance targets in the Strategic Plan are less measurable. Government agencies also generally carry out performance appraisals once a year and the results of the assessment have not been utilized for employee coaching.

\section{Conclusion}

Building a merit system within the government bureaucracy in Indonesia is a must, given the importance of reducing political intervention in the appointment and promotion which has so far caused the agency's performance to be suboptimal and the effectiveness of government administration to below. through the application of the merit system, the careers of ASN employees will be determined by the competence and performance of each and this can encourage them to continue to improve their ability to carry out their duties. Providing strong regulations that could support merit system implementation, then socialized and internalized to all government institutions.

Strengthen the collaboration between KASN with multi-stakeholders', namely: Ministry of Administrative and Bureaucratic Reform (KemenPANRB) and all government agencies both central and local governments; national institute of public administration (NIPA or LAN); National Civil Service Agency (BKN); media and non-government 
organizations. Implementation of the merit system. ASN management which is merit-based is not easy to realize, requiring not only high costs but also competent human resource managers in the field of human capital and being tough in facing various challenges, internal and external to government agencies. the implementation of the merit system will only succeed if there is a change in mindset from ASN employees and also the Personnel Management Officer, as well as political support from all stakeholders.

Strengthen the role and function, including the capacity of the Indonesian Civil Service Commission (KASN) in supervising and fostering the development of a merit system will also determine whether what is mandated in the ASN Law that is a professional, integrity, neutral and high-performing ASN employee can be realized in a short time.

\section{References}

\section{Books}

Johnston, M. (2009). Perspective, persistence, and learning. Thousand Oaks, CA: Sage.

Chassamboulli, A dan Gomes, P. (2017). Jobs for the Boys! Meritocracy, Public Sector Pay and Human Capital Accumulation, University of Cyprus, and Universidad Carlos III de Madrid. Pardede, A.C. and Mustam, M. (2017), Manajemen Sumber Daya Manusia Pegawai Negeri Sipil Dalam Rangka Reformasi Birokrasi Di Kabupaten Semarang', Universitas Diponegoro, Semarang.

\section{Book chapter}

Richards, K. C. (1997). Views on globalization. In H. L. Vivaldi (Eds.), Australia in Global World (pp. 29-43). Sydney, Australia: Century.

\section{Journal article}

Cho, Wonhyuk, et. al. (2013). A Cross-Country Study of The Relationship Between Weberian Bureaucracy and Government Performance, International Review of Public Administration, 18 (3), 115-137.

Everest and Philips. (2015). Meritocracy and Public Service Excellent, International Journal of Civil Service Reform and Practice, issue 5, October, 94-98. 
Harel, Gedaliahu, H., and Tzafrir, Shay, S. (2001). HRM Practices in the Public and Private Sectors: Differences and Similarities, Public Administration Quarterly, 25 (3/4), 316-350.

Ko, Jaekwon, and Walter, Smith, A. (2013). The Relationship Between HRM Practices and Organization Performance in The Public Sector: Focusing on Mediating Roles of Work Attitudes. International Review of Public Administration, 18 (3), 219-231.

Meyrina, S. (2016). Implementasi Peningkatan Kinerja Melalui Merit Sistem Guna Melaksanakan Undang-Undang Aparatur Sipil Negara No. 5 Tahun 2014 di Kementrian Hukum dan HAM (Implementation of Performance Improvement through Merit System in Utilizing the Act on Civil State Apparatus Number 5 Year 2014 at The Ministry of Law And Human Rights), Jurnal Ilmiah Kebijakan Hukum, 10 (2), 175-185.

Perry, James L. (1986). Merit Pay In the Public Sector: The Case for A Failure of Theory, Review of Public Personnel Administration, 7 (1), 51-69.

Svensson, Goran, and Wood, Greg. (2009). Inculcating the Ethos of Public-Sector Codes of Ethics in Sweden: A Longitudinal Approach, Corporate Governance, 9 (2), 175-188.

Tong, Caroline Haiyan, Jeffrey D, Straussman and Walter D, Broadnax. (1999). Civil Service Reform in the People's Republic of China: Case Studies of Early Implementation, Public Administration \& Development, 19 (2), 193-206.

Yoon, Kun, and Kim, Chulwoo. (2016). Components of expertise of public officials in emergency management in Korea: An exploratory study, International Review of Public Administration, 21 (1), 37-56.

\section{Regulations}

Government of Indonesia Law (UU) Number 5 of the Year 2014 on Civil Service

Government of Indonesia Regulation (PP) Number 11 of the year 2017 on Civil Service Management.

Ministerial Regulation of PANRB (PermenPANRB) Number 13 of the year 2014 on the Procedures for Filling the Position of High Leadership at Government Institutions.

\section{Table and Figures}

Table 1.

Quality Position of Governance, Comparing between Indonesia and ASEAN Countries 


\begin{tabular}{|c|c|c|c|c|c|c|c|c|c|}
\hline \multirow[t]{2}{*}{ No } & \multirow[t]{2}{*}{ Country } & \multicolumn{2}{|c|}{$\begin{array}{c}\text { Global } \\
\text { Competitiveness } \\
\text { Index (GCI) } \\
\end{array}$} & \multicolumn{2}{|c|}{$\begin{array}{c}\text { Ease Of Doing } \\
\text { Business } \\
\text { (EoDB) } \\
\end{array}$} & \multicolumn{2}{|c|}{$\begin{array}{c}\text { Corruption } \\
\text { Perceptions } \\
\text { Index }\end{array}$} & \multicolumn{2}{|c|}{$\begin{array}{l}\text { Government } \\
\text { Effectiveness } \\
\text { Index }\end{array}$} \\
\hline & & Rank & Score & Rank & Score & Rank & Score & Rank & Score \\
\hline 1 & Singapore & 3 & 5,71 & 2 & 84,57 & 7 & 84 & 1 & 100 \\
\hline 2 & Korea & 26 & 5,07 & 4 & 83,92 & 52 & 53 & 41 & 80,77 \\
\hline 3 & Malaysia & 23 & 5,17 & 25 & 78,43 & 55 & 49 & 51 & 75,96 \\
\hline 4 & Thailand & 32 & 4,72 & 26 & 77,44 & 101 & 35 & 71 & 66,35 \\
\hline 5 & Indonesia & 36 & 4,68 & 72 & 66,47 & 90 & 37 & 98 & 53,37 \\
\hline 6 & Vietnam & 55 & 4,36 & 68 & 67,93 & 113 & 33 & 99 & 52,88 \\
\hline 7 & Philippines & 56 & 4,35 & 113 & 58,74 & 101 & 35 & 101 & 51,92 \\
\hline
\end{tabular}

Source: World Bank, Global Governance Index, Transparency International 2018 
Figure 1.

Mapping of Merit Implementation for Civil Service Apparatus Management (ASN) in Several Ministries in 2019

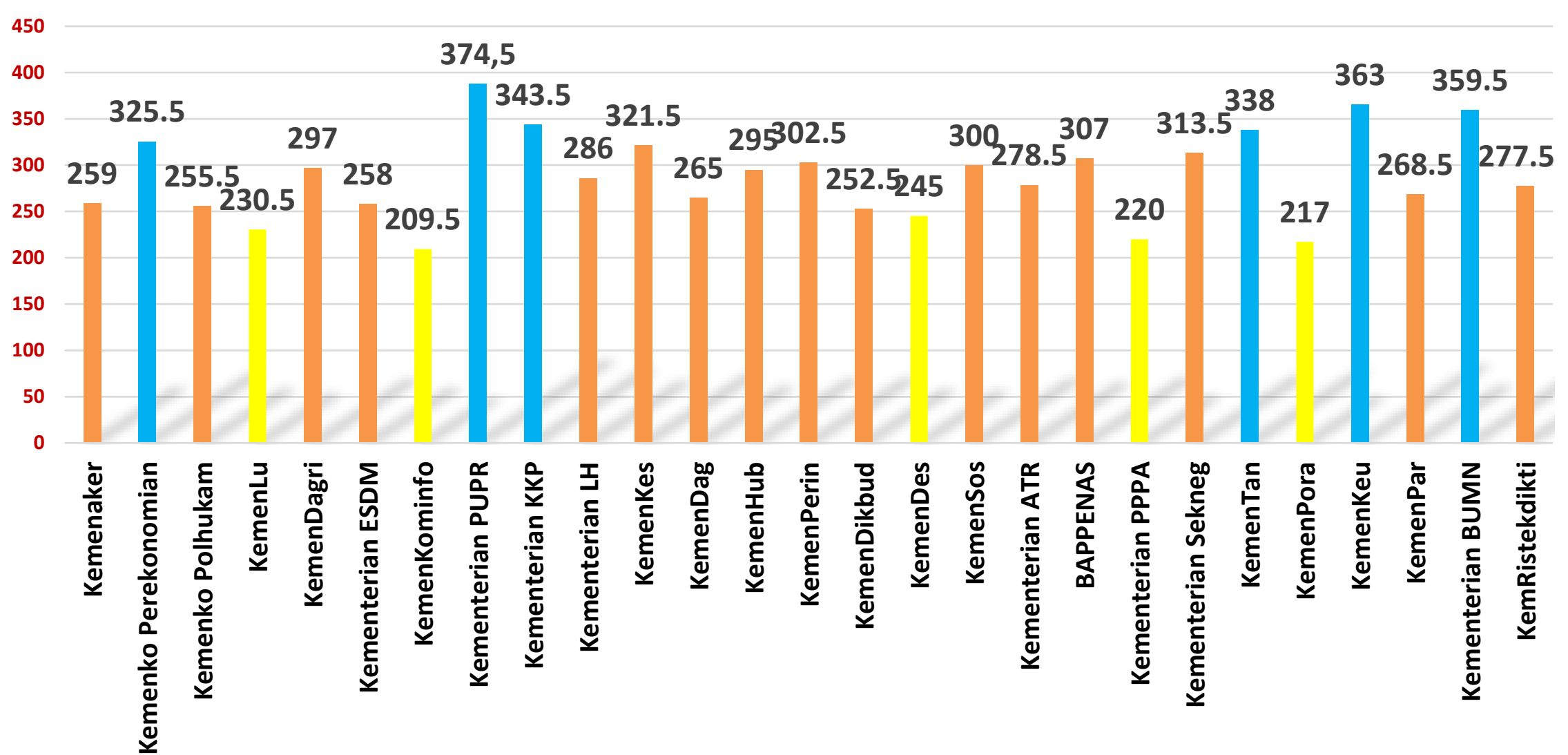

Source: Research and Development System, Indonesian Civil Service Commission (KASN), per November 2019
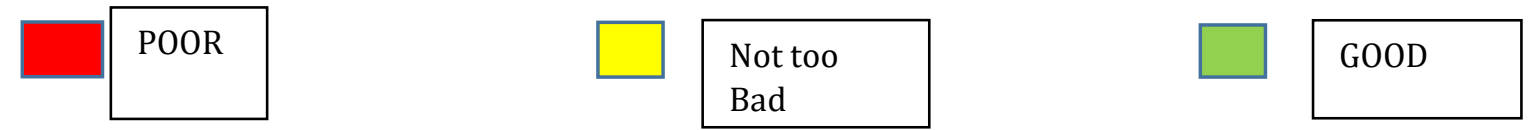
Figure 2.

Mapping of Merit Implementation in Civil Service (ASN) Management in Several Non-Ministries Level in 2019

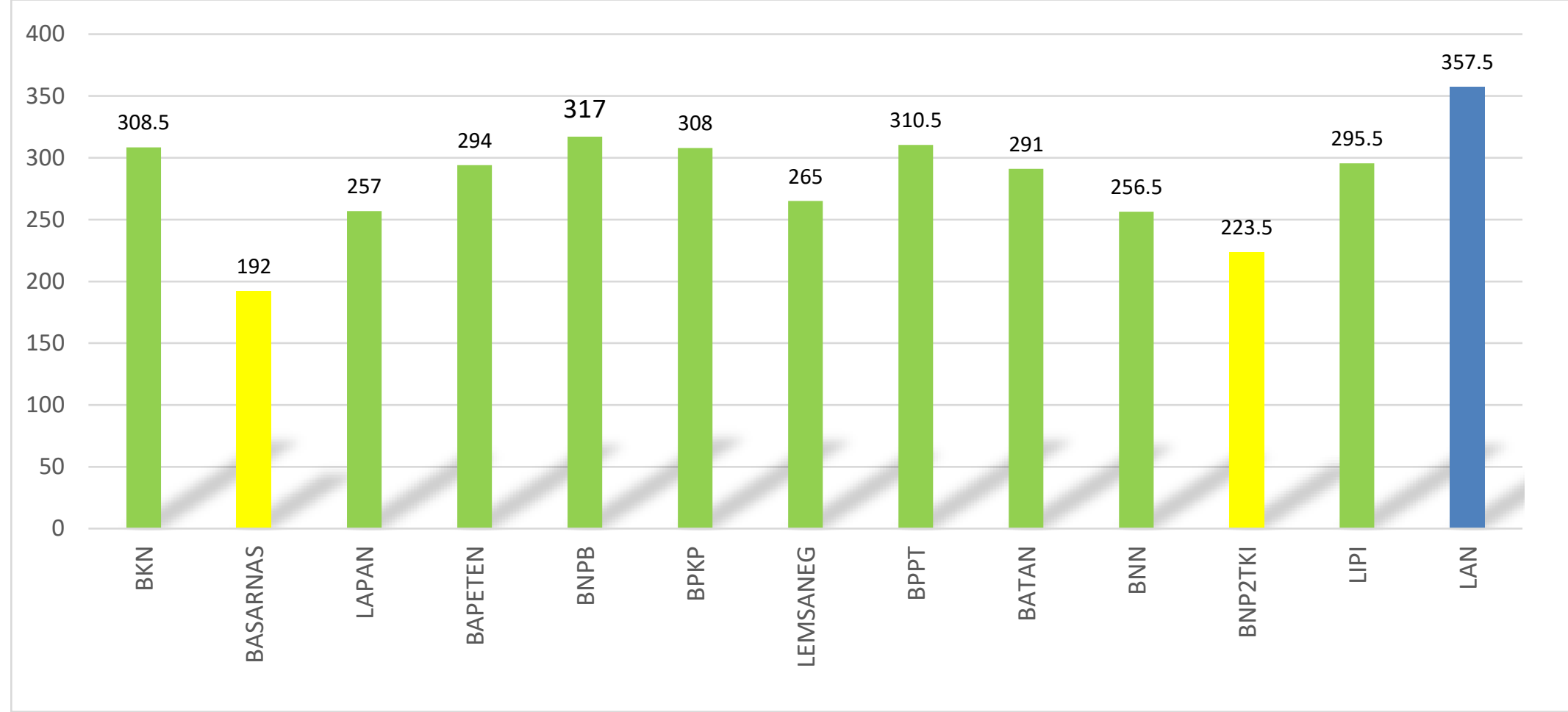

Source: Research and Development System, Indonesian Civil Service Commission (KASN), per November 2019

POOR

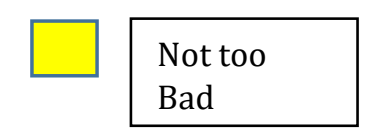

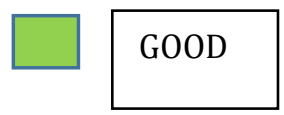

VERY GOOD 
Figure 3.

Mapping of Merit Implementation in Civil Service (ASN) Management in all Local Government Provinces in 2019

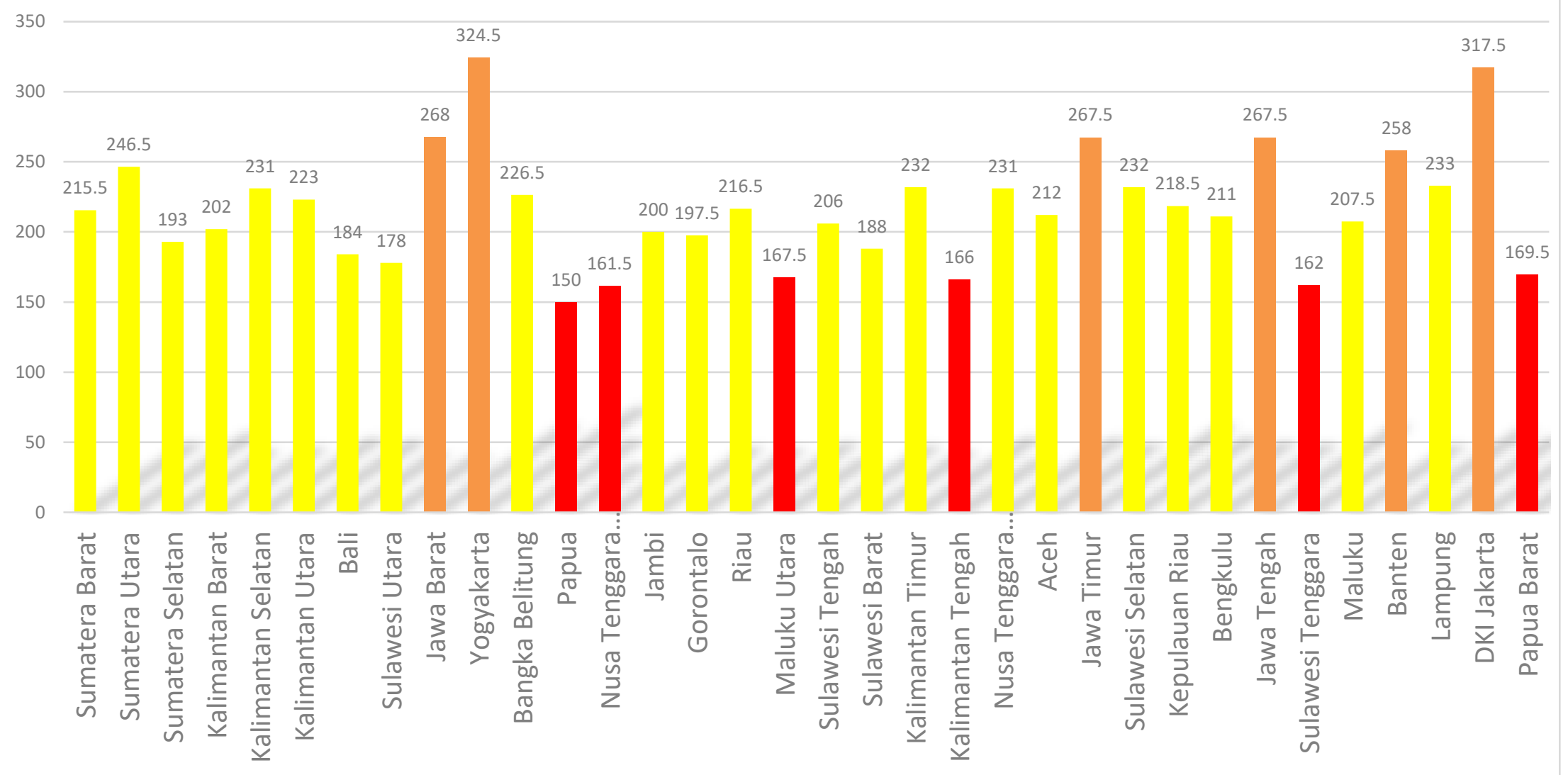

Source: Research and Development System, Indonesian Civil Service Commission (KASN), per November 2019
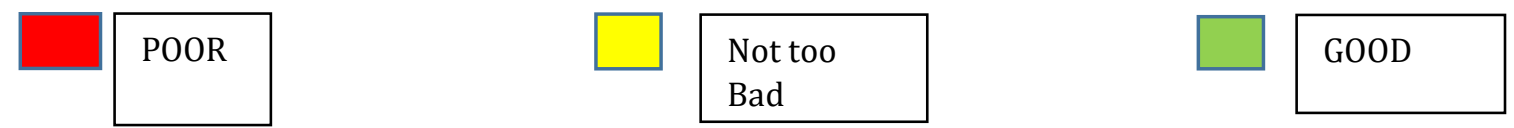
Figure 2.

Mapping of Merit Implementation in Civil Service (ASN) Management in Several Non-Ministries Level in 2019 400

350

300

250

200

150

100

50

0

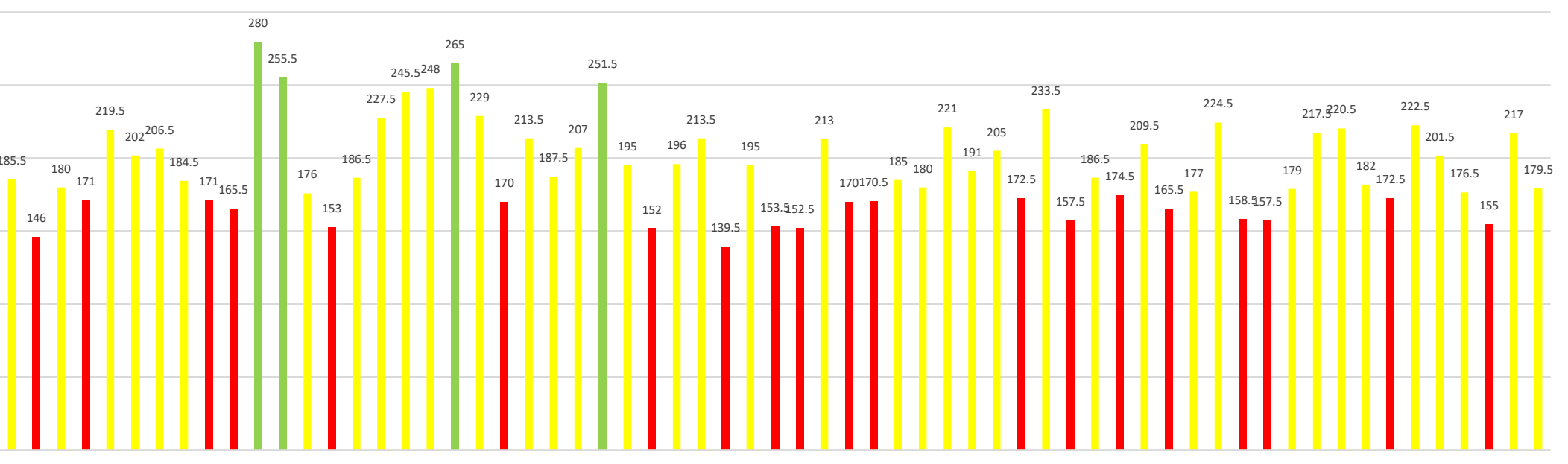

POOR
Pesearch and
Pond
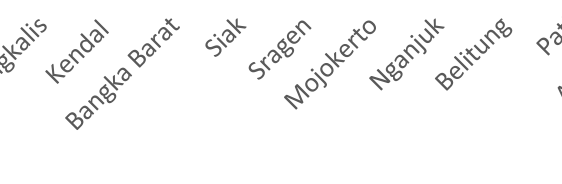

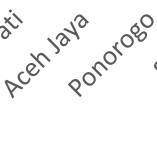

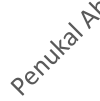

Source: Research and Development System, Indonesian Civil Service Commission (KASN), per November 2019
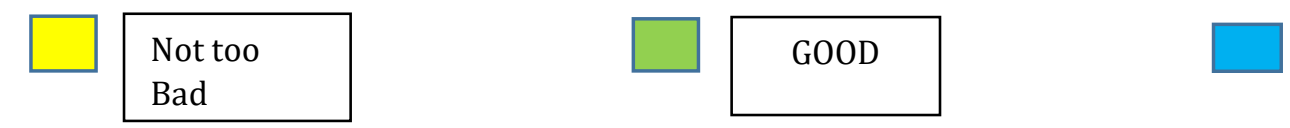
Figure 4.

Mapping of Merit Implementation in Civil Service (ASN) Management in some Local Government Districts and Cities per November 2019

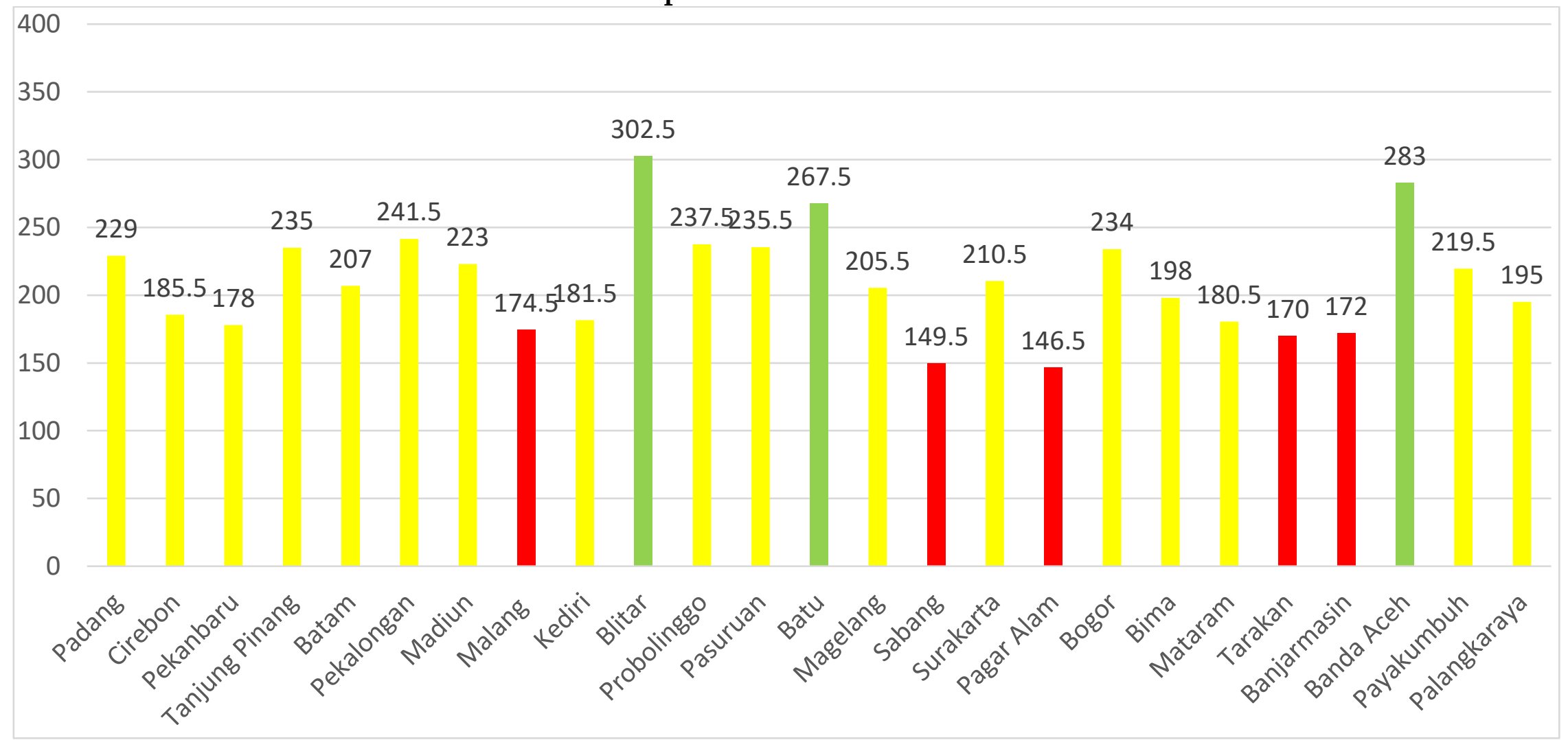

Source: Research and Development System, Indonesian Civil Service Commission (KASN), per November 2019
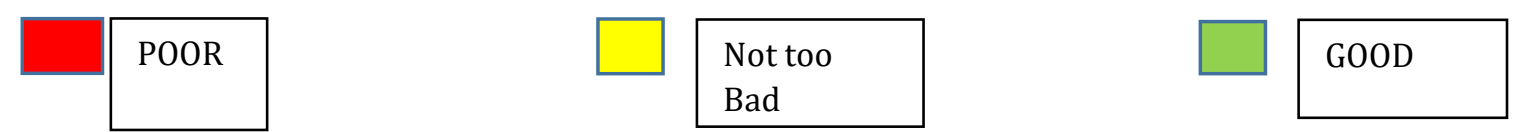

VERY GOOD 
Figure 5: Overview Achievement of Merit Values on Civil Service Management in Central Java Province

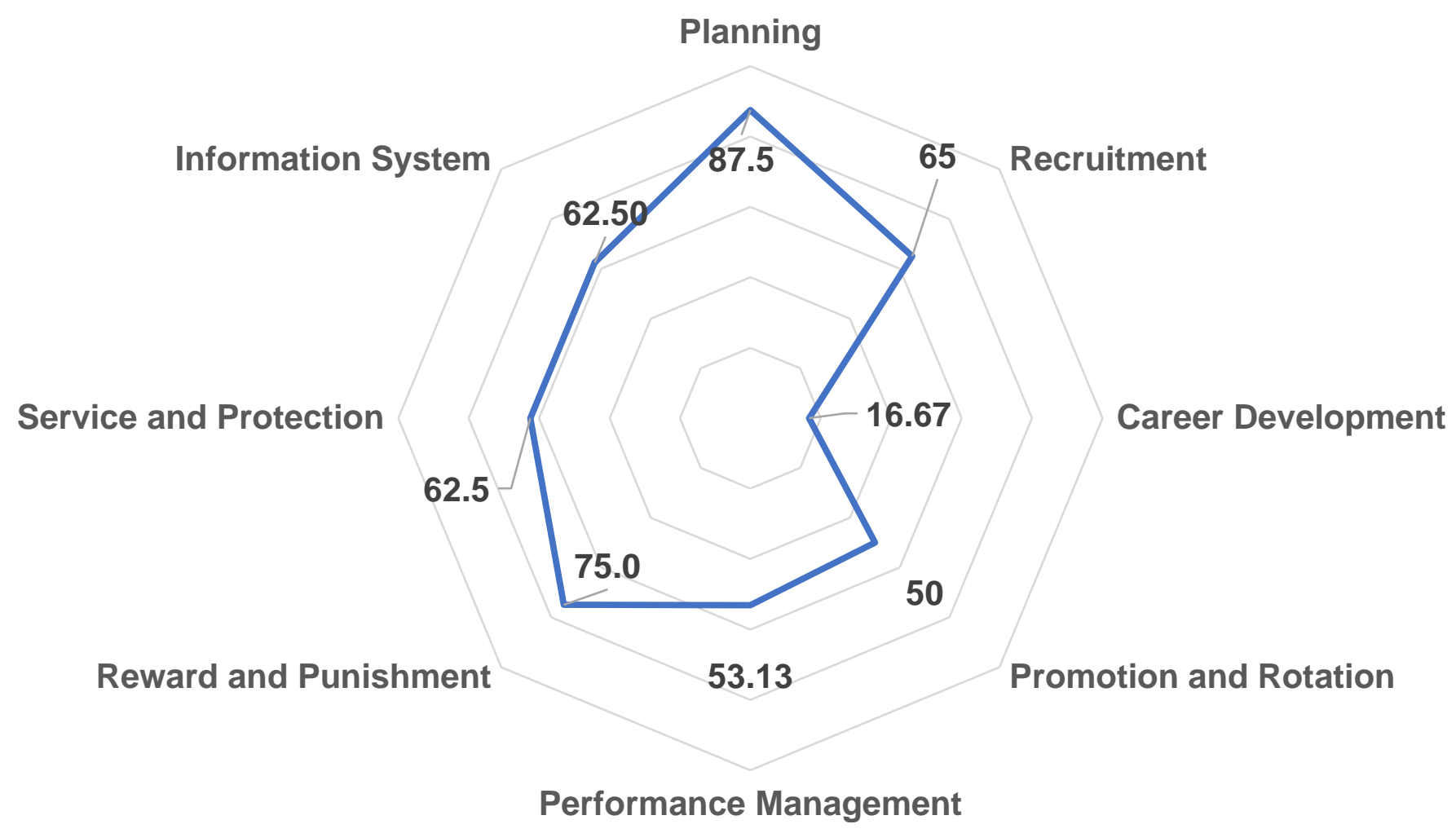

